\title{
TOURIST DECISION IN MOUNT MERBABU NATIONAL PARK, INDONESIA
}

\author{
Putri Indah Riadi ${ }^{*}$ Faida Lies Rahayu Wijayanti, Fandeli Chafid, Purwanto Ris Hadi \\ Faculty of Forestry, University of Gadjah Mada, Indonesia \\ *E-mail: indah riadi putri@yahoo.com
}

\begin{abstract}
This study aims to determine decision-making regarding tourist visit, preferences and average time of visit. The study was conducted using quantitative approach. The results exhibit travelers' characteristics are dominated by males within 15-30 age range. The average income is generally less than IDR 2,000,000 with monthly travel budget up to IDR 500,000 due to visiting motivation, that is, quiet and natural environment. Most tourists were originally from Central Java region, so transportation used in general is a private motorcycle and travel cars. Tourists' visitation is for recreation purposes with friends which generally last for two days with about 2 to 5 times annualy. Lastly, travel activity most favored by tourists is camping.
\end{abstract}

\section{KEY WORDS}

Visitation decision, tourist, national park, mount Merbabu, ecotourism.

Forest in national park area possesses natural resources capable to provide various benefits for human life in the surrounding and areas beyond. These populations are affected directly and indirectly. National park tourism is one of such benefits. Along with the increase in population and economic needs, it increases the need for forest resources. There is another supporting aspect in the form of customs, culture, cool weather, and the beauty of natural panorama. The increasing population rises density, routine work and activities which create a sense of saturation. Therefore the population requires entertainment in choosing tourist attractions such as tours to the national park. According to Pitana and Gayatri (2005), prior to conducting a tour, a prospective tourist first performs a mental process to decide when to travel, travel duration, destination, transportation method and so on. The process of visitation decision making is very important for tourism development as it is related to the facts affecting decisions and these factors may affect promotion process (tourism marketing). Understanding the visiting decision-making process is as important as the basis of the promotion process in product planning and market segmenting or target marketing.

Market segmentation could be observed from the existence of budget inclusion on tourism commodities in the form of hike routes in Selo District's Mount Merbabu National Park. The budget was implemented in 2014 and 2015 which are respectively IDR $110,517,000$ and IDR 403,560,500 (Mount Merbabu National Park, 2015). This indicates tripled visitations compared to the previous year. Based on statistical data survey of Mount Merbabu National Park (2014), domestic tourist visits in 2010, 2011, 2012, 2013, 2014 and 2015 respectively reached $11,700,23,598,27,431,25,012,25,578$ and 24,600 people. This indicates an increase in the level of tourist visits to Mount Merbabu National Park. The influence of tourist visiting decisions is very meaningful for the development of the tourism industry and local revenue, therefore, domestic and foreign tourists are interested to visit (Rantetadung, 2012).

According to Pitana and Gayatri (2005), tourist visitation decision-making process went through several crucial phases which are described as follows. First, prospective tourists respective needs and desire to travel. They weigh whether they ought to conduct the trip or not. Second, prospective tourists need information and assessment towards the destination. This is conducted by contacting a travel agent, studying promotional materials (brochures, leaflets, mass media), or discussing with experienced people beforehand. This information is evaluated to decide on alternatives related to various destinations to be visited in allotted time and budget. Third, the decision to travel, including tourist destination, accommodation 
type, travel method, and activities to be undertaken in the tourist destination. Fourth, travel preparation and tourist experience by booking accommodation and travel method, conducting personal preparations, and finally carrying out the travel activities. Fifth, tourists do an assessment on their travelling satisfaction. During the trip to tourist destination and after returning to the country of origin, the tourists consciously or unconsciously always evaluate their travel which will affect visitation decisions in the future.

There are several factors that influence the decision-making process as described by Pitana and Gayatri (2005):

1. Tourist characteristics, both social and economic characteristics (age, education, income, and previous experience), as well as behavioral characteristics (such as motivation and the value held)

2. Awareness of travel benefits, knowledge of destinations to be visited, the image of the destination

3. Trip features, including distance, stray duration, time and cost constraints, uncertainty risk, and the level of confidence in the travel agency

4. The advantages of the tourist destination, which includes the type and nature of the attractions offered, service quality, physical and social environment, political situation, accessibility, and local community attitude towards tourists. This is in line with the regulation of Boyolali Regent No. 21 The year 2015 regarding work plan Boyolali Regency Regional Development in 2016. One of which discussed the potential of regional development for tourism, in increasing tourists decision in choosing a tourist destination to Merbabu Mountain National Park.

Therefore, this study was conducted to determine factors affecting tourist decision in visiting Mount Merbabu National Park. It is conducted in order to create tourism management strategy in increasing tourist visits. The objectives of this research are as follows:

1. To determine tourist characteristics related to gender, age, income, origin, travel time in Selo hike route Mount Merbabu National Park

2. To determine characteristics of tourist visit related to type, purpose, habit, the preferred activity on the Selo hike route Mount Merbabu National Park.

3. To determine the characteristics of tourists budget utilized to travel to Mount Merbabu National Park

4. To determine infrastructure facilities found in the Selo Hike Route Mount Merbabu National Park.

The research result could be used as ecotourism information development of Mount Merbabu National Park, Selo District, Boyolali Regency.

\section{METHODS OF RESEARCH}

The location of the study was determined by pulDRosive sampling (as the purpose of the study), at Wonolelo Resort Selo Hike Route in Selo District Boyolali District. Based on the revised zonation document of Mount Merbabu National Park (2014) as stipulated in Forestry Ministerial Decree number 135 / Menhut-II / 2014, it is an area of $\pm 5,725$ hectares, geographically located at $11^{00} 32$ 'BT $-110^{\circ} 48^{\prime}$ BT and $7^{0} 38$ 'LS $-7^{\circ} 48^{\prime} \mathrm{LS}$. This area has the highest peak at 3,142 meters from sea level. Topographic range from light to mountainous (slope starts from $8 \%$ to above $40 \%$ ). The study was conducted in September and October 2016.

Research Sample. Research respondents were tourists who visited Mount Merbabu National Park, Boyolali Region within the limit of data collection period for 2 months using indepth interview and research questionnaire. The number of research samples is determined based on the consideration of the Slovin formula, namely:

$$
\mathrm{n}=\frac{N}{1+N e^{2}}
$$


Where: $\mathrm{n}=$ total sample; $\mathrm{N}=$ total population (140 people); $\mathrm{e}=$ toleratable sampling mistake $(5 \%)$.

Total tourist sampling formula:

$$
\mathrm{n}=\frac{N}{1+N e^{2}}=\frac{140}{1+140(0,050)^{2}}=\frac{140}{1+0,40}=\frac{140}{1,40}=100 \text { tourist }
$$

Tourist samples obtained were 100 tourists. These provide narrative and general description of tourist decision to visit Merbabu Mountain National Park.

The sampling method is carried out by accidental sampling. Researched selected tourists who are in the research area and willing to complete the questionnaire and be interviewed in detail. Respondent selection is based on several factors such as being in productive age of at least 15 years, able to receive and respond to questions asked directly, the level of income used for students and unemployed is the amount of money (in the form of allowance, grant, scholarship, prize) obtained, physically and spiritually healthy, and can communicate well.

Data Analysis Approach Method. Data analysis approach method utilized is a mixture of quantitative and qualitative methods (mixed methods research). This approach method combines qualitative methods with the support of quantitative methods aimed at obtaining a complete picture and a thorough understanding (narration and data in numbers). Based on the results of the research data analysis approach, the researcher can clearly explain the characteristics of tourists, visits, budgets, supporting facilities and infrastructure of Mount Merbabu National Park.

\section{RESULTS AND DISCUSSION}

Tourist Characteristics. In general, tourist characteristic in Selo Hike Route is tourists possessing conventional psychographic characteristics. Conventional psychographic characteristic is are people demanding perfection of service and completeness of tourism infrastructure (Weiler et al., 1992). It was seen from tourists effort to visit Mount Merbabu National Park Ecotourismby setting aside their spare time, preparing equipment and supplies, as well as route planning.

Table 1 - Tourist Characteristic Category

\begin{tabular}{|c|c|c|c|}
\hline No. & Tourist Characteristic & Category & Percentage \\
\hline 1 & Gender & $\begin{array}{c}\text { Male } \\
\text { Female }\end{array}$ & $\begin{array}{l}86 \\
14\end{array}$ \\
\hline 2 & Age & $\begin{array}{c}15-20 \text { years old } \\
21-30 \text { years old } \\
>30 \text { years old }\end{array}$ & $\begin{array}{c}48 \\
51 \\
1\end{array}$ \\
\hline 3 & Income & $\begin{array}{c}0 \\
<\text { IDR } 2.000 .000 \\
\text { IDR 2.000.000 - 5.000.000 } \\
\text { IDR 5.000.000 - } 10.000 .000 \\
\text { IDR } 10.000 .000-20.000 .000\end{array}$ & $\begin{array}{c}1 \\
63 \\
13 \\
22 \\
1\end{array}$ \\
\hline 4 & Place of Origin & $\begin{array}{c}\text { West Java } \\
\text { Central Java } \\
\text { East Java } \\
\text { South Sumatera }\end{array}$ & $\begin{array}{l}21 \\
53 \\
15 \\
11\end{array}$ \\
\hline 5 & Travel Time & $\begin{array}{c}<2 \text { hours } \\
2-4 \text { hours } \\
>4 \text { hours }\end{array}$ & $\begin{array}{l}22 \\
28 \\
50\end{array}$ \\
\hline
\end{tabular}

Source: Research primary data (2016).

Gender Characteristic. Tourist decisions are also influenced by personal variables (Kotler, 2005). These characteristics include aspects such as age, life cycle stage, occupation, economic situation, income, and lifestyle. Gender characteristic information is 
required to determine dominant tourists in order to produce activities planning to be conducted at Mount Merbabu summit during camping. The results of this study analysis aim to determine the type of tourist attraction favored by tourists based on gender/sex that come Selo hike route in Mount Merbabu National Park. Most tourists are males (86\%), while the remaining $14 \%$ are women. This is caused by men's physical strength that are more productive than women. This is in line with Tazkia's statement (2012) that male tourists $(60 \%)$ are more dominant than female by $40 \%$ at hot springs tourist attraction in Wonosobo.

Age Characteristic. Information on age characteristic is required to determine the dominant age of tourists to be used as a promotional target of ecotourism development program plan. Based on the research result, tourist visiting Selo Hike Route are within age range $20-30$ years $(51 \%), 15-20$ years $(48 \%)$, and tourists aged $>30$ years $(1 \%)$. Youth stamina between 15-30 years is higher than those aged at $>30$ years. Therefore, the average tourist aged 20-30 has a suitable market on this tour, with activities such as transfer of knowledge related to agricultural activities of various types of horticulture other than hiking activities. Tazkia (2012) stated that tourists are dominated by respondents who are in productive age at an average of 15-29 years. Similarly, in Nahriya's research (2015), tourists in Umbul Songo are mostly male (53\%) with age range within $21-25$ years. Similar tourist characteristic is caused due to most tourists are within 20 to 30 years age range. These tourists are relatively healthy, concentrated on the association of friends, not having family or small children. Therefore activity chosen is to enjoy the beauty of nature by performing various challenges in the hike route.

Income Characteristic. Information on tourist income characteristics was determined to determine tourist categories capable of spending the time to travel with appropriate budget type. Research result exhibits income level of < IDR 2,000,000 (63\%), IDR 5,000,000$10,000,000$ (22\%), IDR 2,000,000-5,000,000, IDR 0, and IDR 10,000,000-20,000,000 at $1 \%$ respectively. Most tourists are within category < IDR 2,000,000, as this category is dominated by students and college students who obtained an allowance from their parents. The group of IDR 5,000,000-10,000,000 was dominated by workers. This is in line with Prasetyo's research (2013) stating that tourist income averaged at IDR 1,645,667.

According to Keliwar's statement (2015), the average income of tourist visiting Pampang Samarinda cultural village is generally more than IDR 3,000,000 (32.1\%). This is due to the uniqueness of Pampang cultural attraction such as the existence of a historical building architecture, sculpture, beads craft, dances, and traditional Dayak musical instruments. Therefore foreign tourists or domestic tourist from outside the island have a greater interest. In contrast to tourists in Selo hike route, these are generally dominated by adolescents to adults levels possessing intermediate level of income.

Place of Origin Characteristic. Place of origin characteristic information is needed to determine the level of promotion and tourists' curiosity in Mount Merbabu National Park Ecotourism. Research result exhibits that most tourists were originated from Central Java $(53 \%)$, West Java (21\%), East Java (15\%), and South Sumatra (11\%). Tourists come from Central Java and East Java possess better accessibility compared to others as they would need to spend less time to travel to the National Park. Tourists from West Java and South Sumatra visiting Mount Merbabu National Park is led by their curiosity in seeing the differences on available attraction compared to tourist areas in their home region. According to Keliwar's research (2015), Pampang cultural village is mostly visited by tourist hailing from Samarinda (51.8\%). This is similar to tourist in Mount Merbabu National Park coming from Central Java (53\%), who is basically originated from the same province as the National Park itself. According to Wanti's research (2014) tourists in Kina Bukit Tanggul garden comes from Bandung (66.67\%) and Sumedang (3.33\%).

All this proves that most tourists come from the city where the tourist area is located. It can be concluded that Kina Bukit Tanggul does not have high promotion level and attractions diversity. Most tourist attractions are visited by tourist from the same region it's located at and regions within close proximity. Closer distance allows the tourist to apply optimal travel time and budget. Selo Hike Route tourist is originated from regions with a distance of more than $80 \mathrm{~km}$ or 1.5 hours travel time (47\%). It indicates that Mount Merbabu 
National Park has a unique attraction on the flora, fauna, cultural arts architecture, music or traditional dances, as well as the diversity of agricultural horticultural crops.

Travel Time Characteristic. Information on travel time characteristic is needed to determine tourist level of curiosity to visit the ecotourism area Mount Merbabu National Park. Research result exhibits tourist had to go through travel time> 4 hours (50\%), 2-4 hours $(28 \%),<2$ hours $(22 \%)$. Tourists who traveled 2 to more than 4 hours visited Mount Merbabu National Park due to unique scenery not owned by other National Parks. Tourists who traveled 2 hours and less were driven by the desire to conduct vacation in optimal time allocation.

According to Tazkia's research (2012), the average tourist tourist who traveled $5 \mathrm{~km}$ or less than 10 minutes from their residence or place of origin. This is dissimilar compared to tourist visiting Mount Merbabu National Park. In general, tourists had to travel $\pm 180 \mathrm{~km}$ or 240 minutes to reach their destination, assuming that they traveled $30 \mathrm{~km}$ in \pm 45 minutes. Therefore tourists are more attracted to visit Mount Merbabu National Park than hot springs in Wonosobo.

Tourist Visit Characteristic. In general, a tourists visiting Selo Hike Route in Mount Merbabu National Park are those with conventional psychographic characteristics. Conventional psychographic characteristic is a character that demands perfection of service and completeness of tourism infrastructure (Weiler et al., 1992). It can be seen from tourist visit to ecotourism area in Mount Merbabu National Park by considering various things such as: with whom they make a visit, visitation purpose, stay duration, factors encouraging their visit, and preferred activity.

Table 2 - Tourists Visitation Characteristic Categories

\begin{tabular}{|c|c|c|c|}
\hline No. & Tourist Visitation Characteristic & Visitation Category & Percentage \\
\hline 1 & Type & $\begin{array}{c}1 \text { person } \\
2-5 \text { person } \\
6-8 \text { person } \\
>8 \text { person }\end{array}$ & $\begin{array}{c}8 \\
40 \\
32 \\
20 \\
\end{array}$ \\
\hline 2 & Purpose of Visit & $\begin{array}{c}\text { Recreation } \\
\text { Vacation } \\
\text { Health } \\
\text { Education } \\
\text { Religion } \\
\text { Sport } \\
\text { Business } \\
\text { Culture } \\
\text { Work Assignment } \\
\text { Family Visit } \\
\end{array}$ & $\begin{array}{c}53 \\
75 \\
42 \\
18 \\
6 \\
46 \\
6 \\
6 \\
11 \\
16 \\
\end{array}$ \\
\hline 3 & Behavior & $\begin{array}{c}1 \text { time } \\
2-5 \text { times } \\
>5 \text { times }\end{array}$ & $\begin{array}{c}44 \\
53 \\
3\end{array}$ \\
\hline 4 & Length & \begin{tabular}{|c|}
1 day \\
2 days \\
3 days \\
\end{tabular} & $\begin{array}{c}45 \\
49 \\
6 \\
\end{array}$ \\
\hline 5 & Motivation & $\begin{array}{c}\text { Close Distance } \\
\text { Easiness } \\
\text { Adequate Transport } \\
\text { Low Expense } \\
\text { Nature Potential and Attraction } \\
\text { Quiet and Natural Environment }\end{array}$ & $\begin{array}{l}41 \\
34 \\
46 \\
20 \\
52 \\
61\end{array}$ \\
\hline 6 & Preferred Activity & $\begin{array}{c}\text { Tracking } \\
\text { Hiking } \\
\text { Camping } \\
\text { Education } \\
\text { Star Observation } \\
\text { Religion } \\
\end{array}$ & $\begin{array}{l}72 \\
60 \\
85 \\
15 \\
23 \\
13\end{array}$ \\
\hline
\end{tabular}

Source: Researcher Primary Data (2016). 
Type Characteristic. Information on the tourist visit type is needed to determine the level of promotion and curiosity on Mount Merbabu National Park Ecotourism. The analysis results exhibit that tourists come in 2-5 group members (40\%), 6-8 group members (30), 8 group members $(20 \%)$, and 1 person $(8 \%)$. Tourist mostly comes in $2-5$ group members. In general, there are couples who want to enjoy the scenery of Merbabu National Park. Group consisting of 6-8 people or more are a group of students and university students intent to experience adventure dissimilar to other attractions in other tourist destinations. According to Tazkia's research (2012), in general, tourists visit in a group or bring their family for the trip. This is similar to tourist visiting Selo Hike Route in Mount Merbabu National Park. In general, they visit in 2-5 group members. This is in line with Premono's research (2008) stating that tourists visit TWA Punti Kayu with relatives or friends (57\%).

Purpose of Visit Characteristic. Every tourist has a purpose or occasion to travel to Selo Hike Route in Mount Merbabu National Park. Based on the research result, the tourist has the following purpose or occasion: holiday (75\%), recreation $(53 \%)$, sport $(46 \%)$, and health (42\%). Education, family visits, work assignments, religious, business, and culture are respectively $18 \%, 16 \%, 11 \%, 6 \%, 6 \%, 6 \%$. Tourists visiting for holiday and recreation purposes generally come on weekends and public holidays such as Javanese New Year. According to Rizkhi's statement (2014), tourists on Palu Bay tour travel to their respective destination to enjoy the nature while on recreation to exercise, refresh, reflect fatigued body and mind due to daily activity, and restore health (78,99\%). In general, tourists visiting Selo Hike Route and Palu Bay come for vacation purposes. Nahriya's research (2015) stated that most tourists in Umbul Songo come with recreation and vacation purpose (36\%). Therefore Umbul Songo tourists have similar purposes to those visiting Selo Hike Route. Holidays can be classified into weekends (Saturday and Sunday) and public holidays which are common days for tourist to visit.

Behavior. Information on tourist behavior in one year is needed to determine the level of tourist satisfaction in ecotourism area of Mount Merbabu National Park. Research result exhibits that tourists generally conduct $2-5$ visits per year (53\%), 1 visit per year (44\%), and more than 5 visits a year (3\%). In general tourist visits Mount Merbabu National Park 2-5 times a year which indicates that these tourists generally return to this tourist attraction. They were drawn by available attractions, objects, beautiful scenery, and distinct cultural aspects. Based on Prasetyo's research (2013), Mount Merbabu National Park tourists visit 2 times annually which is more compared to those visiting tourism village. According to Tazkia (2012), tourists visit Wonosobo hot springs around 1 to 5 times, which is similar to Selo Hike Route in Mount Merbabu National Park. According to Nahriya (2015), Umbul Songo tourists generally revisit the tourist destination (70\%). Therefore both Umbul Songo and Selo Hike Route tourists possess similar desire to return to a respective tourist destination.

Variety of scenic beauty can be seen from the planting activities of various types of horticultural crops along Selo Hike Route. This motivation that causes tourists to return, therefore the natural potential of nature in the form of horticulture species diversity can be a potential development of agrotourism in Merbabu Mountain National Park. This is in line with Koswara's research (2005) stating that tourists' dynamically growing preferences and motivation as well as the tendency of tourists visit natural environment led to the development of agro-based tourist attraction.

Duration Characteristic. Information on tourists' stay duration is needed to determine the tourists's stay duration in Mount Merbabu National Park Ecotourism. Research result exhibits that tourists generally stay around 2-days (49\%), 1-day (45\%), and 3-days (6\%). The tourists generally stay for two days starting from Friday night to Sunday morning. Tourists who stay for one day come from a distant area therefore having limited time to spend in the location. There are also tourists coming from nearby regions who ride motorcycles to tourist attraction hence having limited time constraint as well. Nevertheless, in case of 3 days visit is generally caused by heavy rain occuring during the trip. Therefore the tourists had to extend their stay. According to Sitohang's research (2008), tourists generally visit Tuktuk Siadong in Simanindo District for more than 72 hour (49\%). Their stay duration is longer compared to tourist in Selo Hike Route who generally stays for 48 hours 
(48\%). Tuktuk Siadong tourists come from abroad. These international tourists are interested to participate in events featuring cultural diversity, landscape, and community social life. They generally spent more than 24 hours. On the other hand, tourists on Selo Hike Route are merely enjoying the scenery in Mount Merbabu. According to Nahriya (2015), most tourists in Umbul Songo area around the springs of Mount Merbabu National Park Kopeng Resort does not spend the night, but merely conduct activities for one day (77\%). In contrast to tourists visiting Mount Merbabu National Park, most conduct activities for 2 days as there are various activities along Selo Hike Route which could consume at least 14 hours.

Motivation Characteristic. Every tourist has the motivation or encouragement to travel to Selo Hike Route in Mount Merbabu National Park. Marsinko et al (2002) state that an individual's recreational visit is based on expectations of the activity benefits. Research result indicates that most tourist visiting Selo Hike Route in Mount Merbabu National Park are drawn by a quiet and natural environment (61\%), natural potential and attraction as well as the local community (52\%). Adequate transportation, close proximity, easy access to climbing routes, and low cost are $46 \%, 41 \%, 34 \%, 20 \%$ respectively. Tourist is generally motivated by nature potential and human attraction, as local community conduct 'cultural wisdom' activities such as New Javanese year, Saderanan (cemetery cleaning and maintaining ritual), Sedekahan (feast) and so forth. Adequate transportation is supported by adequate transportation facilities such as travel vehicle rental and motorcycle. Furthermore, the low cost incurred is reflected in admission fee, accommodation costs, or snacks with affordable prices for low to high society member.

Tourist is attracted to natural potential and attractions such as the various types of agricultural horticulture crops planted. There are chilies, cabbage, tomatoes, green onions, carrots, pumpkin on farmers' land which can be seen from along the main road of Selo District up to the hike route itself. Nature attraction exhibits farmer activity conducting planting, maintaining, or harvesting horticulture crop. This activity can be used as education media and promotion of the agricultural product for tourists. In line with Koswara's statement (2005), agrotourism is one type of tourism that utilizes agricultural business as a tourist attraction, combining agricultural and tourism activities. This provides a signal for the development opportunities of diversification of agribusiness products which means it would encourage new development area for the region.

According to Tazkia's research (2012), tourists' motivation is low expenses, which is dissimilar to tourist visiting Selo Hike Route in Mount Merbabu National Park. They are drawn by the presence of natural and human attractions as well as potential. According to Kastolani's research (2016), tourists possess physical and psychological motivation level at $37.68 \%$ in Cimahi tour. Cimahi tourist motivation is lower compared to those in Selo Hike Route, which is caused by similar tourism objects such as community agricultural and livestock caretaking activities. Nevertheless, Selo Hike Route's especially featured climbing and camping activities as well as observing flora and fauna from the summit of Merbabu Mountain.

According to Nahriya's research (2015), Umbul Songo Mount Merbabu National Park's tourist is influenced by tourism activities factors. Most tourists have never visited the location (5.4); colleague or family invitation (5.6) which has a somewhat influential meaning. The highest driving factor for visiting Umbul Songo is family and friend invitation (5.6). On the other hand, the highest driving factor for tourist visiting Selo Hike Route is drawn by the beautiful scenery and villages' natural condition (61\%).

Preferred Activity Characteristic. Every tourist has the motivation or encouragement to travel to the Selo Hike Route in Mount Merbabu National Park. Research result exhibits tourist are interested in camping activity (85\%), tracking (72\%), hiking, animal, educational religious observations are $60 \%, 23 \%, 15 \%, 13 \%$, respectively. Preferred activities such as camping enable tourists to spend time at the top of the mountain with relatives and watch the sunset. Tracking activity enables tourist to determine relatives' character during undesirable events. Tourists can also enjoy the trip by looking at various types of forest plants and beautiful fauna. Introduction of flora fauna ecosystem types in Mount Merbabu National Park is conducted by tour guides while on a trip or at posts alongside the hike route. According to 
Sitohang's research (2008), Tuktung Siadong tourists have an average level of interest in tourism program activities during Visit Indonesia Year 2008 (61.6\%). Tuktung Siadong tourist interest rate $(61.6 \%)$ is smaller compared to Selo Hike Route $(85 \%)$ interest rate towards available attraction. Selo Hike Route offers natural beauty and challenges that encourage adrenaline rush.

Expenses Characteristic. Information on Expense characteristics is required to view or estimate the expenses incurred during a trip. Iqbal's research (2006) states that travel expenses consist of transportation costs (travel and return trip), accommodation (lodging) costs while on site, consumption fee, entrance fee, and other expenses. Semet's research (2012) states that the travel expenses consist of transportation costs, accommodation costs, consumption costs and communication costs.

Table 3 - Expense Characteristic

\begin{tabular}{|c|c|c|c|}
\hline No. & Expense Characteristic & Category & Percentage \\
\hline \multirow{3}{*}{1} & \multirow{3}{*}{ Monthly Budget (/budget) } & < IDR 500,000 & 35 \\
& & IDR 500,001-1,000,000 & 12 \\
\hline \multirow{2}{*}{2} & \multirow{3}{*}{ Income (/budget) } & IDR 1,000,001-1,500,000 & 73 \\
& & $<$ IDR 2,000,000 & 24 \\
\hline
\end{tabular}

Source: Researcher Primary Data (2016).

Budget Characteristic. A number of expenses incurred by travelers reflect the tourist WTP (income) for recreational services. Individual assessment of a recreational visit is based on expectations of activity benefits (Wijayanti, 2009). Research result exhibit that tourist allotted monthly travel budget around <IDR 500,000 (55\%), IDR 500,001-1,000,000 (33\%), and IDR 1,000,001 -1,500,000 (12\%). Tourists with <IDR 500,000 budgets are mostly students or university students. They generally drive from their residence to tourist destination less than 4 hours. Tourists with budget category IDR 500,001-1,000,000 are students and workers residing in regions required more than 4 hours of travel. Therefore these tourists required to amass a certain amount of money prior to travel. Tourist with budget category IDR 1,000,001-1,500,000 generally resides in the region requiring more than 4 hours of travel. Nevertheless, they have relatives living in the nearby region which requires less than 4 hours of travel, therefore these tourist spends more than 2 days.

Average Mount Merbabu National Park tourist budget is <IDR 500,000 but more than IDR 120,000 . This is reinforced by the assumption tourists' expenses for 2 days 1 night is at least of IDR 120,000. According to Prasetyo's research (2013), average tourism village tourist budget is IDR 103,333. According to Menuh (2016), backpacker tourists spend average budget costs incurred to travel to Bali around IDR 117,250 a 1 day. Backpacker tourist spending in Bali is 1.5 times greater compared to Selo Hike Route's tourist expenses which amount to IDR 60,000 per day. Balinese living cost is higher than the villagers in Selo district. According to Nahriya (2015), Umbul Songo tourist travel costs are in the range of IDR 100,000 - IDR 200,000 (43\%) and IDR10,000 to IDR 50,000 (37\%). Average Umbul Songo tourist's expenses are almost the same as Selo Hike Route Mount Merbabu National Park tourist which reached IDR 200,000 As average tourist visit the region around 2 to 5 times, it can be concluded that the tourists have a great satisfaction level of existing infrastructure services with prices set by the entrepreneur. This situation is in accordance with Ariyanto's statement (2005) that high prices in a tourist destination will affect tourist decision in making another trip to tourist attraction, therefore demand will be reduced and vice versa.

Income Characteristic. Information or tourist income is required to determine the category of tourist need. Therefore tourist destination manager can create travel program activities in accordance with the tourist range of income or willingness to pay. Research result exhibits that tourist obtained monthly income around <IDR 2,000,000 (73\%), IDR 2,000,000 - 5,000,000 (24\%), and IDR 5,000,001 - IDR 10,000,000 (3\%) Income categories 
$<$ IDR 2,000,000 is dominated by students and university students, while income category $>$ IDR 2,000,000 are workers. According to Premono (2008), TWA Punti Wood tourist have an average income of IDR 500,000 - IDR 800,000 as the tourist destination is a recreation type for the middle class. TWA Punti Wood income is lower compared to Selo Hike Route tourist income which averages at IDR 1,200,000 with the assumption of minimum income compared to living expenses in Central Java. According to Dwiputra (2013), the average monthly income of tourists in Mount Merapi generally less than IDR 700,000 as most of the tourist are students. On the other hand, Selo Hike Route tourists are generally students and workers.

Available Infrastructure Characteristic. Information on available infrastructure facilities needed to be able to see the satisfaction of tourists related services available sapras in the Mount Merbabu National Park Ecotourism. Tourism activities can be seen from supply and demand factors which is a component of the tourism market (Mulrphy, 1985). The supply is everything consumed or enjoyed by tourists formed by various factors. The result could be dubbed as the tourist product. Demand is a tourist and everything inherent in the selfgenerated tourists by various factors that then form what is called the image of tourism. (Mulrphy, 1985). The demand for tourism is the total number of people traveling to use tourism facilities and services in places far from their respective place of origin.

Table 4 - Facilities Assessment on Several Categories

\begin{tabular}{|c|c|c|c|}
\hline No. & Facilities & Category & Percentage \\
\hline \multirow{3}{*}{1} & \multirow{3}{*}{ Lodging } & Camping ground & 73 \\
& & Cottage & 22 \\
& & Homestay & 85 \\
\hline \multirow{4}{*}{ Facility } & Eateries & 79 \\
& & Place of Worship & 44 \\
& & Parking Area & 53 \\
& & Rest Area & 74 \\
3 & \multirow{3}{*}{ Transport } & Toilet & 65 \\
& & Shopping Area & 39 \\
\hline & & Motorcycle & 60 \\
4 & & Bus & 14 \\
& \multirow{3}{*}{ Infrastructure } & Public / Travel Car & 67 \\
& & Main Road & 78 \\
& & Branch Road & 71 \\
& & Footpath & 59 \\
& & Bridges & 72 \\
\hline
\end{tabular}

Source: Researcher Primary Data (2016).

Lodgings. The first infrastructure facilities are related to the accommodation services such as lodging. Research result exhibits the tourist peruse homestay (85\%), camping ground $(73 \%)$, and cottage $(22 \%)$. Homestay receives many tourists who take advantage of this facility. Tourist can take a stop and rest in this facility on the way up to the summit. Those coming down from the mountain can use this facility to clean up. Some tourist uses this facility to grab some meal and leave their respective vehicles in homestay's parking area. Camping ground category is in several posts to the top of Mount Merbabu, which has been used by tourists to take a break. The cottage is possessed similar function to homestay but the foundation of the house is still grounded cement and wooden walls. The cottage is not often visited by tourists; this is due to the inadequate facilities available. According to Nahriyah (2015), tourist perception on lodging infrastructure in Umbul Songo Mount Merbabu National Park is at 3.5 (normal category). In contrast to the assessment of tourists visiting Selo Hike Route, they rate lodging facility at $85 \%$ or good category. Tourist in Selo Hike Route requires places to rest or stopover compared to those in Umbul Songo.

Facility. Facilities related to this research is parking and shopping facilities. Research result exhibits available facilities in Mount Merbabu National Park is food stalls (79\%), toilets $(65 \%)$, parking, worship, shopping facilities at $53 \%, 44 \%, 39 \%$ respectively. Food stalls 
available are mostly locals setting up small eateries selling local cuisine. They mostly use their house's rooms and terrace to set up eateries. Rest areas provide thick mats, parking lots, places of worship. Shopping facility provided in local houses sells various climbing equipment, snacks, soft drinks, and souvenirs. According to Setiyorini (2012), tourist perception on the availability of facilities in Pekanbaru amounted to $17.64 \%$. This perception is lower compared to Selo Hike Route's shopping facility (39\%). The various facility provided by local community along Selo Hike Route in Mount Merbabu National Park would encourage the tourist to return as it provides comfort and places to rest.

Transport. The third infrastructure facilities are related to the transportation services such as travel car or motorcycle. Research result exhibits tourist perusing public car or travel $(67 \%)$, motorcycle $(60 \%)$, and bus (14\%). Citizens around Mount Merbabu National Park have provided public cars such as travel with approximately 8 units, while inter-city buses are also available in the area around the Mount Merbabu National Park. According to Effendi (2015), most tourists visiting Tangkil Island in Lampung Province use private vehicles $(97.14 \%)$. This is different from the tourist visiting Selo Hike Route which is dominated by travel transportation (67\%). This fact indicates could potentially increase income for Selo District villagers.

Infrastructure. The fourth infrastructure facility is related to the existence of infrastructure facility that serves as a connecting road to the ecotourism area of Mount Merbabu National Park. The result of the analysis study based on the most infrastructure category is the main road of $78 \%$, followed by bridges, branch roads, walkways, and terminals respectively $72 \%, 71 \%, 59 \%, 18 \%$. There are several main roads around the area of the Mountain Merbabu National Park which is an improvement of Selo-Boyolali route. Selo Hike Route often experience landslides resulting from agricultural crops planting on the steep slopes. According to Putra (2013), farmers in Selo district Boyolali Regency cultivate the land without applying the terracing system, sloping cultivation pattern, still cultivate the land with more than $40 \%$ slope level and poor stands of perennials. The potential for landslides could potentially endanger visiting tourists. The nearest terminal available is in the area around Boyolali Regency. According to Setiyorini (2012), the accessibility of tourism in Pekanbaru city is $22.3 \%$ which is significantly lower than the accessibility of Selo Hike Route in Mount Merbabu National Park at $78 \%$. This is because of access added value in Selo Hike Route TNGMb. The available access road to the foot of Merbabu Mountain to as high as $\pm 1600 \mathrm{mdpl}$. Access available to Selo High Route is two paths which went through Magelang and Boyolali City. Magelang City route to the Selo Hike Route in Mount Merbabu National Park Hike Route could be accessed from Yogyakarta - Magelang City - Ketep Merbabu Mountain National Park area with distance $\pm 80 \mathrm{~km}$ using 4 wheels vehicles within \pm 2 hours. While Boyolali City to Selo Hike Route in Mount Merbabu National Park Hike Route could be accessed from Solo - Boyolali - Selo - Mount Merbabu National Park area with a distance of $\pm 65 \mathrm{~km}$ using 4 wheel vehicles in \pm 1 hour 30 minutes travel time.

\section{CONCLUSION AND SUGGESTIONS}

Tourists are generally males (86\%) and women (14\%). Tourists were generally $21-30$ years of age $(51 \%)$, and the lowest was at age $>30$ years $(1 \%)$. Characteristics based on the highest income are in category <IDR 2,000,000 (63\%) and the lowest is IDR 0 to > IDR $10,000,000$. The tourist generally come from Central Java (53\%), and the lowest number of visitor come from South Sumatra (11\%). Travel time are generally $>>4$ hours at $50 \%$, while the lowest is $<2$ hours $(22 \%)$.

Tourist generally comes in $2-5$ group members (40\%) and the lowest is 1 person (8\%). The tourist generally comes on holidays $(75 \%)$ and the lowest was for business, culture and religion occasion (6\%). Tourist generally comes around $2-5$ times a year (53\%) and there are few coming $>5$ times a year (3\%). Characteristics based on length of the visit were in 2 days $(49 \%)$ and a small number stayed for 3 days $(6 \%)$. Tourists are generally drawn by quiet and natural environment $(61 \%)$, and a small number of them were drawn by low expenses 
(20\%). The most preferred activity-based characteristic was camping (85\%) and the least preferred activity was the religious activity (13\%).

Highest monthly budget are at <IDR 500.000 (55\%) and the lowest is at IDR 1,000,001 $-1,500,000(12 \%)$. In general, tourist monthly income is <IDR $2,000,000(73 \%)$ while a small number of them earning IDR 5,000,001 -10,000,000 (3\%).

Most of tourists stay in homestay (85\%) while a small number stayed in cottage $(22 \%)$. The most facilities available are food stalls $(79 \%)$ while the lowest facility available is shopping area (39\%). The most commonly used transportation node used is car or travel vehicle/ rented cars (67\%) and the least common transportation node used is bus $(14 \%)$. Common infrastructure available is main road $(78 \%)$ and the least common infrastructure available is terminal (18\%).

From the research, several suggestions can be made as follows:

1. Factors that become a visiting decision for tourists include gender; age; income or income per month; origin; relatively short travel time; stay duration; purpose and activity; travel expenses; facilities and infrastructure available. These factors should be able to optimize in ecotourism development program.

2. Ecotourism development program should be able to present several agenda designs that are made based on the needs, effective time and tourist need. Suggested design of the agenda are: a) The promotion of natural tourism package is practical outbound activities (without tool aids) consisting of at least 2 kinds of activities accompanied by the provision of small merchandise for the winner of outbound participants in the form of goods symbolizing the regional culture, the implementation takes precedence on the eve of the national holiday, b) The promotion local culture and wisdom coinciding with national holidays.

\section{REFERENCES}

1. Balai Taman Nasional Gunung Merbabu. 2014. Zonasi Taman Nasional Gunung Merbabu (Dokumen Revisi Zonasi). Kementerian Lingkungan Hidup dan Kehutanan. Direktorat Jenderal Perlindungan Hutan dan Konservasi Alam.

2. Dwiputra, R. 2013. Preferensi wisatawan terhadap sarana wisata di kawasan wisata alam erupsi merapi. Jurnal Perencanaan Wilayah dan Kota 24(1), 35-48.

3. Effendi, A., Samsul, B., Rusita. 2015. Nilai ekonomi jasa wisata Pulau Tangkil Provinsi Lampung dengan pendekatan metode biaya perjalanan. Jurnal Sylva Lestari 3(3), 71-84.

4. Iqbal, M. 2006. Analisis Nilai Ekonomi Taman Wisata Alam Laut Pulau Weh di Kota Sabang. Unpublished Graduate Thesis. Bogor: IPB.

5. Joaqui, A. \& Jaume, G.. 2010. Tourist Satisfaction and Dissatisfaction. Annalys of Tourism Research. 37(1), 52-73.

6. Kastolani, W., Sri, M., Ghassani, F. 2016. Hubungan daya tarik wisata dengan motivasi berkunjung wisatawan ke alam wisata Cimahi. Jurnal Manajemen Resort dan Leisure 13(1), 36-43.

7. Keliwar, S. \& Anton, N. 2015. Motivasi dan persepsi pengunjung terhadap objek wisata desa budaya Pampang di Samarinda. Jurnal Manajemen Resort dan Leisure 12(2), $10-$ 27.

8. Koswara, I.H. 2005. Karakteristik dan potensi wisata agro Jawa Barat. Paper presented in Forum Koordinasi Pengembangan Wisata Agro, Jawa Barat Province, Indonesia.

9. Kotler, Philip. 2005. Manajemen Pemasaran di Indonesia: Analisis, Perencanaan, Implementasi dan Pengendalian. Jakarta: Salemba Empat.

10. Marsinko, A., Zawacki, W., \& Bowker, J.. 2002. Travel Cost Method in Planning: A Case Study. Tourism Analysis 6(1),203-211.

11. Murphy, Peter E. 1985. Tourism: A Community Approach. New York: Methuen.

12. Nahriyah, D.A. 2015. Pengembangan ekowisata Umbul Songo Di Taman Nasional Gunung Merbabu Jawa Tengah. Skripsi. Konservasi Sumberdaya Hutan dan Ekowisata IPB, Bogor. 
13. Pitana, I.G. 2005. Sosiologi Pariwisata, Kajian Sosiologis Terhadap Struktur, Sistem, dan Dampak-Dampak Pariwisata. Andi Offset, Yogyakarta.

14. Pitana, I.G. \& Gayatri, P.G. 2005. Sosiologi Pariwisata. Yogyakarta: Andi Offset.

15. Prasetyo, N.J. \& Endah, S. 2013. Bagaimana kesediaan untuk membayar peningkatan kualitas lingkungan desa wisata. Ekonomi dan Studi Pembangunan 14(2), 127-136.

16. Premono, B.T. 2008. Pengaruh perilaku pengunjung terhadap jumlah kunjungan di Taman Wisata Alam Punti Kayu Palembang. Jurnal Penelitian Hutan dan Konservasi Alam 5(5), 423-433.

17. Putra, S. 2013. Strategi Pertanian Berkelanjutan di Kecamatan Selo Kabupaten Boyolali. Unpublished Graduate Thesis. UNDIP, Semarang.

18. Rantetadung, M. 2012. Analisis Pengaruh Dukungan Pemerintah dan Kunjungan Wisatawan Terhadap Pendapatan Asli Daerah Di Kabupaten Nabire. Jurnal Agroforensi 7 (1), 25-32.

19. Rizkhi, I.B. 2014. Preferensi pengunjung terhadap daya tarik objek wisata Teluk Palu di Kota Palu. Jurnal Pembangunan Wilayah dan Kota 10(4), 425-439.

20. Semet, M.M. 2012. Analisis Ekonomi Wisata Alam Berkelanjutan Taman Wisata Alam (TWA) Gunung Meja Manokwari Papaua Barat. Unpublished Graduate Thesis. IPB, Bogor.

21. Sitohang, R. 2008. Promosi Kepariwisataan dan Peningkatan Jumlah Kunjungan Wisatawan (Studi Korelasional Tentang Eektivitas Kampanye Visit Indonesia Year 2008 Dalam Meningkatkan Jumlah Kunjungan Wisatawan Mancanegara di Daerah Tujuan Wisata Tuktuk Siadong Kecamatan Simanindo Kabupaten Samosir. Unpublished Undergraduate Thesis. Fakultas IImu Sosial dan Politik, Universitas Sumatera Utara.

22. Setiyorini, H.P.D. 2012. Pengaruh faktor-faktor penarik kepariwisataan wisatawan asal Malaysia terhadap keputusan berkunjung ke kota Pekanbaru. Tourism and Hospitality Essentials (THE) Journal II(I), 269-290.

23. Tazkia, F.O. \& Banatul, H. 2012. Analisis permintaan objek wisata pemandian air panas Kalianget Kabupaten Wonosobo dengan pendekatan Travel Cost. Diponegoro Journal Of Economics 1(1), 1-10.

24. Wanti, L.W. 2014. Analisis Ekonomi dan Srategi Pengembangan Wisata Kebun Kina Bukit Unggul Kabupaten Bandung. Unpublished Graduate Thesis. IPB, Bogor.

25. Weiler, Berty, Colin. 1992. Spesial Interest Tourism. London: Bellhaven Press.

26. Wijayanti, P. 2009. Analisis Ekonomi dan Kebijakan Pengelolaan Wisata Alam Berbasis Masyarakat Lokal di Kabupaten Administrasi Kepulauan Seribu Provinsi DKI Jakarta. Unpublished Graduate Thesis. IPB, Bogor. 